\title{
Sex Chromatin in Dental Pulp. Performance of Diagnosis Test and Gold Standard Generation
}

\author{
Cromatina Sexual en Pulpa Dental. Rendimiento de la \\ Prueba Diagnóstica y Generación del Gold Standard
}

Iván Suazo Galdames; Ignacio Roa Henríquez \& Mario Cantín L.

\begin{abstract}
SUAZO, G. I.; ROA, H. I. \& CANTÍN, L. M. Sex chromatin in dental pulp. Performance of diagnosis test and gold standard generation. Int. J. Morphol., 28(4):1093-1096, 2010.

SUMMARY: The sex chromatin or Barr body is a condensation of chromatin present at the nucleus of cells in female individuals. Their observation is possible in different cell types and is used for the rapid diagnosis of biological sex. The observation of this condensation in cells of the pulp tissue can be useful in the forensic diagnosis of sex, primarily because of the protection it give dental hard tissues, but its diagnostic value has not been tested. The purpose of this study is to analyze the diagnostic value of the observation of sex chromatin in cells of the pulp tissue. We used 40 premolars and third molars-20 from men with a mean age of 20.6 years (SD 8.8) and 20 from women with a mean age of 20.4 years (SD 7.4). The pulp was obtained from teeth extracted and localized 50 cells per plate. The presence of a cell with visible Barr body was considered positive for women. With these results, we evaluated the diagnostic performance of the test. The performance of the test was $100 \%$; of the 50 cells observed per plate, mean Barr bodies positive cells was 20.4 (SD 0.44 ) in female samples. There was no positive cell in preparations of male subjects. The diagnostic test observation of sex chromatin in dental pulp is a reliable test for sex determination. This study provides a gold standard for performance assessment in which the teeth have suffered extreme physical conditions, such as incineration and dumping.
\end{abstract}

KEY WORDS: Sex chromatin; Barr chromatin; Sex determination; Forensic dentistry.

\section{INTRODUCTION}

Sex determination in forensic medicine is considered one of the first and most important steps. This is usually done with a simple observation of the internal and external physical sexual characteristics. However, the problem arises in determining the sex of skeletons, especially when having only segments or isolated teeth.

Tooth enamel is the hardest tissue in the body, and the teeth remain intact after death, thus making them useful for forensic identification of sex with respect to morphological characteristics (Haga, 1959; Gonda, 1959; Garm, 1964) and soft tissues (Das et al., 2004).

In 1949, Barr and Bertram determined that there was a difference between male and female cells. They found that, in female cells, there was a small chromatin condensation at the nuclei of nerve cells of cats (Barr et al., 1950). This condensation (Barr chromatin or Barr body) also has been found in bone cells (Vernino \& Laskin, 1960), cells of the retina (Teplitz, 1965), and oral mucosal cells (Dixon \& Torr, 1956).

The presence of sex chromatin or Barr bodies in dental tissues has been registered, but the results have been mixed regarding their share and postmortem time required for proper identification (Seno \& Ishizu, 1973; Whittaker $e t$ al., 1975). Furthermore, there is no gold standard to assess its diagnostic value in different climatic conditions, burial conditions, and exposure to physical agents, such as heat and humidity.

Against this background, the purpose of this study is to evaluate the diagnostic performance of Barr body observation for sex determination in healthy teeth, thus establishing a gold standard to evaluate its diagnostic performance variations in different situations. 


\section{MATERIAL AND METHOD}

We used 40 healthy premolars and molars in adult patients aged 24 to 45 years, divided into two groups: 20 men with a mean age of 20.6 years (SD 8.8) and 20 women with an average age of 20.4 years (SD 7.4). The teeth were healthy, extracted by orthodontic indication, and immediately preserved in 5\% formalin solution for an average of 7 days. The pulp was conventionally obtained through the normal access cavity on the occlusal surface of the teeth; dental pulp tissues were obtained using standardized K-files (Dentsply Maillefer, Baillaigues, Switzerland). The tissues were stored immediately after excision in 5\% formalin solution for 7 days. After this time, the tissues were processed for hematoxylin eosin; histological sections with a thickness of $5 \mu \mathrm{m}$ were made at different levels, of which, four sections were randomly selected. They were systematically observed using a trinocular microscope CX21 (Olympus (®) with a $100 \mathrm{X}$ magnification and analyzed using Micrometrics SE Premium software.

Fifty cells were observed per plate, the presence of a cell with visible Barr bodies was considered positive for women. With these results, we evaluated the diagnostic performance of the test.

\section{RESULTS}

The performance of the test was $100 \%$. Of the 50 cells observed per plate, the mean of Barr body-positive cells was 20.4 (SD 0.44) in female samples (Fig. 1). There were no Barr body-positive cells in preparations of male subjects (Fig. 2).

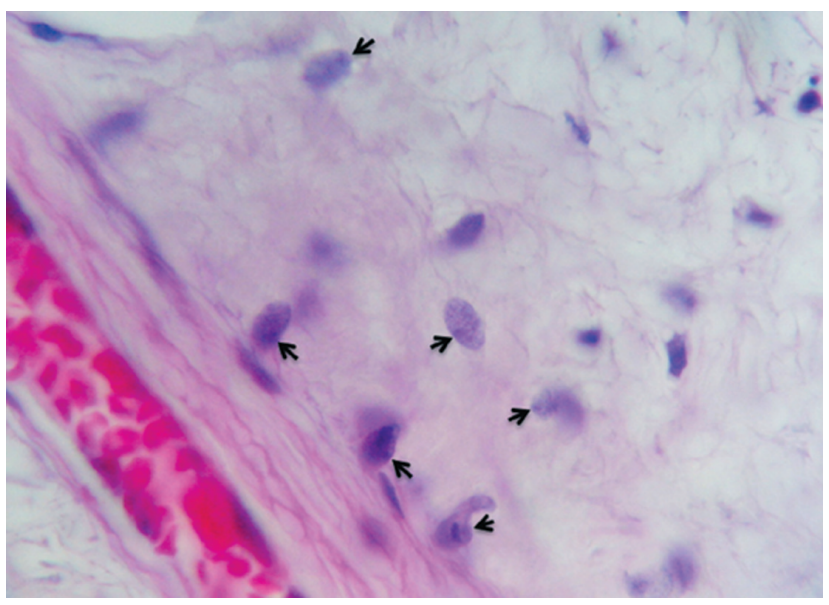

Fig. 1. Photomicrograph of histologic section of female dental pulp stained with hematoxylin eosin (original magnification, 100X). Positive fibroblasts were observed for the observation of Barr bodies. The arrows indicate the characteristic condensation of sexual chromatin.

\section{DISCUSSION}

Sex determination is the first step in forensic identification. There are large number of techniques designed to achieve this goal, such as observation of secondary sexual characters, gonads, and bones (Suazo et al., 2008a, 2009a, 2009b). However, sex determination using residual bone is complex when the remains are segmented or in special pathological conditions (Suazo et al., 2008b). This is where the histological and cellular techniques provide an important contribution (Murakami et al., 2000).

Barr chromatin or Barr bodies and sexual identification method have been described in various tissues (Dixon \& Torr; Vernino \& Laskin, Teplitz) including dental pulp (Das et al.). This is presented as rapid and is easily implemented because it requires little equipment in contrast to techniques, such as PCR (Murakami et al.) and LAMP method (Nogami et al., 2008). Addition of Barr chromatin can be observed with most of the nuclear stains, such as hematoxylin-eosin, Papanicolaou, Feulgen, cresyl violet, aceto-orcein, carbol-fuchsin, and fluorescence (Duffy, 1989).

One of the limitations to the use of this method are the alterations at the chromosomal level because patients with abnormalities can yield false negatives or false positives (Barr, 1959; Daher et al., 1986). In control men, no Barr bodies were reported, and in 46XX women, one Barr body in cell nuclei was observed (Duffy). However, in men and women with aneuploidy, 47XXY men also have a Barr body, and 47XXX women have two (Kelly, 1986).

The results obtained in our study are similar to those

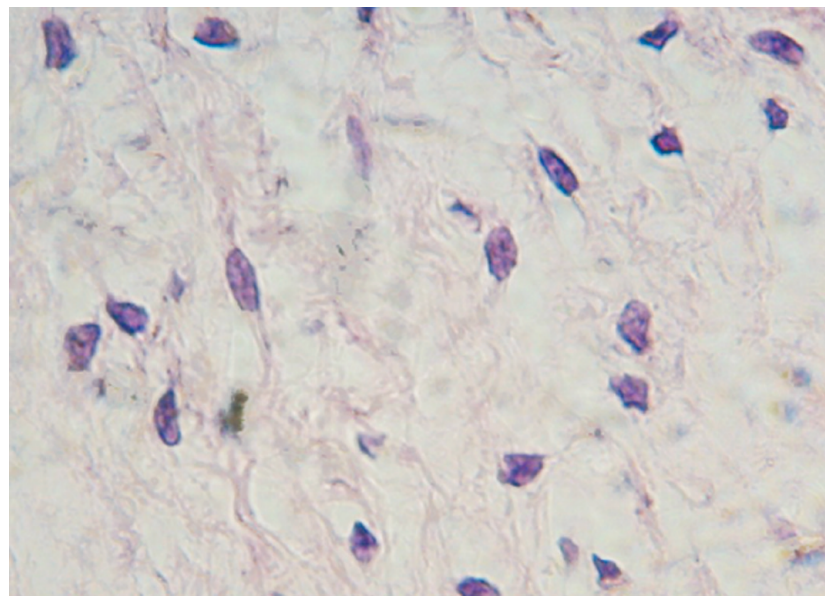

Fig. 2. Photomicrograph of histologic section of male dental pulp stained with hematoxylin eosin (original magnification, 100X). Negative fibroblasts were examined for the Barr body observation. 
reported by Das et al., who reported that $24.92 \%$ of women pulp cells were positive for Barr body observation. Also, Yunis \& Chandler (1979) indicated that in women with a normal karyotype, Barr bodies were observed in approximately $30 \%$ of cellular nuclei, with a range between $15 \%$ and $40 \%$. Barr bodies are probably more frequent than suggested by our results and other authors (Das et al.; Yunis \& Chandler); however, this chromatin adheres to the nuclear membrane, and in histological preparations, Barr bodies tend to hide behind or in front of the nucleoplasm and cannot be identified as such (Duffy).

The performance in our analysis was 100\%, making it comparable to more complex techniques in identifying sex from amplification of DNA, which also show high performance in terms of classification but require more complex work and time to complete the analysis and need special equipment to amplify DNA (Nagami et al.).

Although Barr bodies were found in dental pulp samples (Das et al.), details regarding the postmortem time necessary for a proper identification are varied. Seno \& Ishizu indicate that the corpuscle can be seen up to 5 months after death, whereas Whittaker et al. and Das et al. establish a deadline in five and four weeks postmortem, respectively. Ionesy (1980) stored teeth at room temperature for one year and found that there was a reduction in the ability of sexchromatin staining compared with freshly extracted teeth. Dange et al. (1978) stored samples of permanent teeth, which allowed discrimination of sex through their cells when analyzed four years later.

These differences can be explained by the geographical location because the weather, temperature, and humidity play an important role in the processes of decomposition of biological material. Six to 24 hours after death, there is a decrease in the possibility of clear observation of chromatin, given the process of decomposition by bacterial action (Das $e t$ $a l$.). Duffy et al. (1991) provide the possibility of determining the sexual dimorphism by Barr body in dental pulp after 1 year of dehydration or being subjected to $100^{\circ} \mathrm{C}$ for 1 hour. Seno et al. (1977) found that, in 25-cm teeth buried in mud and sand in the open, sex can be determined in $100 \%$ of cases after 1 month; however, this is reduced by $20 \%$ after 3 months because of cellular decomposition. On the other hand, teeth immersed in running water showed deterioration of cellular structure at 3 days (Duffy). Ionesy extracted and analyzed the dental pulp, refrigerated to $-4^{\circ}$ to $-8^{\circ} \mathrm{C}$ for 15,30 , and 40 days, concluding that it is possible to determine the sex until 30 days.

In general, the methods for determining sex based on bone morphology are difficult to apply in subadults. There also are cases where DNA analysis is not possible because of decomposition caused by environmental conditions (Nagami et al.). Hemanth et al. (2008) found that traditional methods in cases of fire, high-impact accidents, explosions and fragmentation of thermal trauma, and natural disasters make it impossible to determine the sex of skeletal remains, with the exception of methods based on dental pulp, such as Barr chromatin.

This technique is not only limited to healthy teeth, where the chromatin is recognized in fibroblasts. It also is possible to determine sex by differentiation of Barr chromatin in polymorphonuclear neutrophils in teeth with acute and chronic inflammatory processes (Barr, 1957; Larson \& Knapp, 1971).

We conclude that sex determination by observation of sex chromatin or Barr bodies is possible, with $100 \%$ accuracy, based on the observation of 50 cells obtained by a random procedure from healthy dental pulp. We suggest the analysis of this method in various situations of forensic importance, such as time of death, special conditions of burial, temperature, and calcination to assess any changes in terms of diagnostic value.

SUAZO, G. I.; ROA, H. I. \& CANTíN, L. M. Cromatina sexual en pulpa dental. Rendimiento de la prueba diagnóstica y generación del gold standard. Int. J. Morphol., 28(4):1093-1096, 2010.

RESUMEN: La cromatina sexual o de Barr es una condensación de cromatina presente a nivel del núcleo de las células de individuos de sexo femenino. Su observación es posible en diversos tipos celulares y es utilizado para el diagnóstico rápido del sexo biológico. La observación de esta condensación en células del tejido pulpar puede ser útil en el diagnóstico forense del sexo, principalmente debido a la protección que los tejidos duros dentarios le otorgan, sin embargo su valor diagnóstico no ha sido analizado. El propósito de este estudio es analizar el valor diagnóstico de la observación de la cromatina sexual en células del tejido pulpar. Se utilizaron 40 premolares y terceros molares maxilares, 20 de hombres con una media de edad de 20,6 años (DS 8,8) y 20 de mujeres con una edad media de 20,4 años (DS 7,4). La pulpa fue obtenida a partir de piezas extraídas, se realizó la extirpación pulpar y el tejido fue procesado para H-E. Se seleccionaron aleatoriamente 4 placas histológicas, las cuales fueron observadas de manera sistemática utilizando un microscopia Olimpus CX21 con aumento 100X, localizándose 50 células por placa. La presencia de 1 célula con cromatina sexual visible se consideró positivo para sexo femenino. Con estos resultados se evaluó el rendimiento diagnóstico de la prueba. El rendimiento de la prueba fue del $100 \%$, de las 50 células observadas por placa, la media de células cromatina sexual positiva fue de 20,4 (DS 0,44) en muestras de sexo femenino. No se observó ninguna célula positiva en preparaciones de sujetos de sexo masculino. La prueba diagnóstica observación de la cromatina sexual en pulpa dentaria es una prueba confiable para la determinación del sexo. Este estudio establece un gold estándar para la evaluación del rendimiento en los que las piezas dentarias han sufrido de condiciones físicas extremas como incineración, inmersión, etc.

PALABRAS CLAVE: Cromatina sexual; Cromatina de Barr; Determinación del sexo; Odontología forense. 


\section{REFERENCES}

Barr, M. L.; Bertram, L. F. \& Lindsay, H. A. The morphology of the nerve cell nucleus, acording to sex. Anat. Rec., 107:283, 1950.

Barr, M. L. Sex chromatin and phenotype in man. Science, 130(3377):679-85, 1959.

Barr, M. L. Dysgenesis of the seminiferous tubules. Br. J. Urol., 29:251-7, 1957.

Daher, N. V.; Be, R. C. \& Youlton, R. R. Cromatina de Barr: análisis de su valor actual. Rev. Chil. Pediatr., 57:506-9, 1986.

Dange, A. H.; Malvankar, A. G. \& Madiwale, M. S. Determination of the sex origin of teeth. Arch. Kriminol., 162:115-9, 1978.

Das, N.; Gorea, R. K.; Gargi, J. \& Singh, J. R. Sex determination from pulpal tissue. JIAFM, 26:50-4, 2004.

Dixon, D. \& Torr, J. B. D. Sex chromatin in oral smears. BMJ, 2:799-800, 1956.

Duffy, J. B.; Waterfield, D. J. \& Skinner, M. C. Isolation of tooth pulp cells for sex chromatin remains. Foren. Sci. Int., 49:12741, 1991.

Garm, S. M. Sex difference in tooth size. J. Dent. Res., 43:306, 1964.

Gonda, K. The sex difference in size of the teeth. J. Anthropol., 67:151-63, 1959.

Haga, M. A study of sex distinction in the teeth. Jpn. J. Legal Med., 13:582-90, 1959.

Hemanth, M.; Vidya, M.; Nandaprasad \& Bhavana, V. K. Sex determination using dental tissue. Medico-legal Update, 8:712, 2008.

Larson, J. S. \& Knapp, S. J. Sexual dimorphism in beaver neutrophils. J. Mammal, 52:212-5, 1971.

Ionesiy, A. G. On the Possibility of Teeth Sexing by Cytological Proceeding. Sudebno-Meditsinskaia Experitiza, 23:27-8, 1980

Kelly, T. E. Clinical Genetics and Genetics Counselling. $2^{\text {nd }}$ Ed. Chicago, Year Book Medical Publishers, 1986. pp.125-58.

Duffy, J. An appraisal of the stability of sex chromatin and the $H-Y$ molecule in forensic contexts. Thesis (M.A.), Simon Fraser University, 1989.

Murakami, H.; Yamamoto, Y.; Yoshitome, K.; Ono, T.; Okamoto, O.; Shigeta, Y.; Doi, Y.; Miyaishi, S. \& Ishizu, H. Forensic study of sex determination using PCR on teeth samples. Acta Med. Okayama, 54:21-32, 2000.

Nogami, H.; Tsutsumi, H.; Komuro, T. \& Mukoyama, R. Rapid and simple sex determination method from dental pulp by loopmediated isothermal amplification. Forensic Sci. Int. Genet., 2:349-53, 2008.

Seno, M. \& Ishizu, H. Sex identification of human tooth. Int. J. Forensic Dent., 1(8):8-11, 1973.

Seno, M. Sex Identification of the Human Tooth by Y Chromatin in the Nucleus of Dental Pulp Cell. Jpn. J. Legal Med., 31:172-9, 1977.

Suazo, G. I. C.; Zavando, M. D. A \& Smith, R. L. Sex determination using mastoid process measurements in Brazilian skulls. Int. J. Morphol., 26:941-4, 2008a.

Suazo, G. I. C.; Zavando, M. D. A. \& Smith, R. L. Evaluating accuracy and precision in morphologic traits for sexual dimorphism in malnutrition human skull: a comparative study. Int. J. Morphol., 26:876-83, 2008b.

Suazo, G. I. C; Zavando, M. D. A \& Smith, R. L. Sex determination in mandibles in the first year of life by a quantitative approach. Int. J. Morphol., 27:113-6, 2009a.

Suazo, G. I. C; Russo, P. P.; Zavando, M. D. A \& Smith, R. L. Sexual dimorphism in the foramen magnum dimensions. Int. J. Morphol., 27:21-3, 2009 b.

Teplitz, R. L. Sex chromatin of cone cells of human retina. Science, 150:1828-9, 1965.

Vernino, D. M. \& Laskin, D. M. Sex chromatin in mammalian bone. Science, 132:675-6, 1960.

Whittaker, D. K.; Llewelyn, D. R. \& Jones, R. W. Sex determination from necrotic pulpar tissue. Brit. Dent. J., 139:403-5, 1975.

Yunis, J, J. \& Chandler, M. E. Medical Microscopy and Other Body Fluids. In: Todd, Sanford, Davidsohn, Clinical Diagnosis and Management Laboratory Methods. Henry, J. B. (16 ${ }^{\text {th }}$ Ed). Philadelphia, WB Saunders, 1979. pp.820-56.

\section{Correspondence to:}

Prof. Dr. Iván Suazo Galdames

Morfología

Avenida Lircay s/n oficina $\mathrm{N}^{\circ} 104$

Universidad de Talca, CHILE

Email: isuazo@utalca.cl

Received: 22-06-2010

Accepted: 14-09-2010 